\title{
Picking Up the Pieces: \\ Embodied Theory in Bessie Head's A Question of Power
}

\section{Elinor Rooks}

\begin{abstract}
This article analyzes Bessie Head's novel A Question of Power (1974) as a work of vernacular theory engaged with the interactions among power, identity, goodness, and suffering. The text's difficulties are seen, first, as characteristics of embattled theory, in which there is no possibility of safe remove or calm reflection. Further, these difficulties are read as tactical, engaging the text and its reader in a form of madness which destabilizes the realities formed by power. Finally, a fundamental tenet of Head's theory, "Be ordinary," is interrogated: how can ordinariness be disentangled from conformity? Being ordinary may be understood, per Deleuze and Guattari, as becoming everyone - a process through which Head's protagonist, Elizabeth, experiences the shattering of her identity. Elizabeth's schizophrenic breakdown becomes, ultimately, a position from which she is able to theorize the repressive operations of identity and the intimate functionings of power.
\end{abstract}

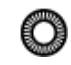

Bessie Head's 1973 novel, A Question of Power, follows the mental disintegration of Elizabeth, a mixed-race South African refugee living in Botswana. Elizabeth increasingly struggles to separate her nightmares from reality, particularly as her visions seem to rehearse the very questions of race, sex, and morality that have troubled her waking life. Although this novel revisits themes and situations familiar from Head's previous works When Rain Clouds Gather (1968) and Maru (1971), the style of A Question of Power is markedly more experimental and abstract. This stylistic difficulty seems at odds with the novel's stated egalitarianism, particularly its emphasis on the importance of "being ordinary." This article will explore this tension, interrogating the connections between the novel's fragmented style and its larger project. The text's slippery language and its overloaded symbolism serve as tools for destabilizing identity in favor of cycles of connection and becoming.

In arguing that A Question of Power is engaged in a creative destruction of identity, this article makes use of theoretical concepts developed by Gilles Deleuze and Félix Guattari, particularly those of the "Body without Organs" and 
"becoming imperceptible." The Body without Organs represents a state of existence outside of social roles - beyond or beneath them. There are many ways of becoming a Body without Organs: a transcendent escape from ego, for instance, or an oppressive denial of individual personhood. Becoming imperceptible represents another means by which one might become a Body without Organs: the individual assumes one identity after another, disappearing within so many contradictory roles that his/her selfhood disintegrates. These concepts will help not only to articulate the nature of Elizabeth's mental fragmentation in A Question of Power but also to resolve the tension between the novel's difficulty and its politics of the ordinary.

In using Deleuze and Guattari to read A Question of Power, this article cannot help but call up the long-standing tensions between postcolonial theory and Deleuze, dating back to Gayatri Spivak's denunciation of Deleuze and Foucault's Eurocentrism in "Can the Subaltern Speak?" This theoretical debate has been ably elucidated in books such as Peter Hallward's Absolutely Postcolonial (2001), Simone Bignall and Paul Patton's Deleuze and the Postcolonial (2010), and Lorna Burns and Birgit M. Kaiser's Postcolonial Literatures and Deleuze (2012). While not intervening directly in this debate, this article seeks to demonstrate the practical usefulness of Deleuzo-Guattarian concepts in engaging with a notoriously challenging postcolonial text. The particular usefulness of Deleuze and Guattari's thinking lies in its flexibility and nimbleness, in the creation of what Deleuze termed "intellectually mobile concepts" (qtd. in Bignall and Patton 9). Although Deleuze has been criticized for being insufficiently political (as indeed was Head), Bignall and Patton note that "Deleuzian philosophy is a political practice that actively resists forms of conceptual capture by creating movement in thought, beginning lines of flight that prompt an established representation of worldly reality to flee" (9). By understanding the radical, creative potential of challenging reality itself, Deleuze and Guattari are well positioned to assist in a reading of A Question of Power. Moreover, Deleuze and Guattari provide concepts that could advance 
postcolonialism's engagement with non-realist texts, as well as with more subtle, intimate, or abstract forms of resistance.

In her novel A Question of Power, Head presents us with a text whose fragmentations seem to mirror the disordered and meaningless experience of schizophrenia. However, this fragmentation's consonance with schizophrenia is not symptomatic but strategic, a deliberate attempt to evade the version of reality constructed by the powerful, a reality that imposes inclusive and exclusive identities - most obviously, racial, sexual, and moral. By tracing Elizabeth's experience of schizophrenic breakdown, Head theorizes a path by which her protagonist confronts, shatters, and attempts to evade these identities. Through this destruction of identity, Head constructs a radical theory of power - a theory which requires, finally, the egalitarianism of becoming ordinary. Here, however, to be ordinary does not mean to be meek or simple-minded, nor does it mean simply to become like others. It means to be without singular identity while participating in all identities, to become everyone and everything, thus enacting Deleuze and Guattari's Body without Organs. This process confers moments of transcendent peace and beauty, but it is more usually savagely painful. It is also a process which endlessly repeats itself, in a constantly renewed struggle for understanding - and this, indeed, is the process of reading A Question of Power.

Head's novel is complex, challenging, and disorienting, and it is often also bewildering and frustrating. Near the beginning of the novel, however, Head offers a statement which comes close to summing up her methodology and which can help us to understand and navigate the text's difficulty: "One might propose an argument then, with the barriers of the normal, conventional and sane all broken down, like a swimmer taking a rough journey on wild seas" (15). In this text, Head does just that. A Question of Power is a work of theory, and it is an embattled theory: theory for survival; theory with no vessel, no safe remove; a turbulent and chaotic theory, constantly in motion. 
This kind of theorization, which takes place beyond the reaches of philosophical discourse, has been dubbed "vernacular theory," a concept developed by Houston A. Baker, Jr., Henry Louis Gates, Jr., and Chikwenye Okonjo Ogunyemi. These writers argue that to talk about one's world is to theorize it, and the theories thus formed are vernacular theories. Vernacular theories are as varied and varying as the communities and individuals that produce them. As Thomas McLaughlin puts it, vernacular theory is "theory that would never think of itself as "theory" " (5), and it importantly assumes that "individuals who do not come out of a tradition of philosophical critique are capable of raising questions about the dominant cultural assumptions" (5). Baker uses the term vernacular theory to refer particularly to what we might term "outsider theory," whereas McLaughlin describes his use of the term as "more abstract," encompassing "the practices of those who lack cultural power and who speak a critical language grounded in local concerns" (5-6). A vernacular theoretical approach will encourage us to read $A$ Question of Power - with all of its strangeness - as situated and connected, as speaking from and to the world, as doing theory. This approach, aided by concepts from Deleuze and Guattari, will enable us to read the text's strangeness and difficulty as crucial to enacting a certain kind of theory: in this case, a theorization of power at once intimate and cosmic.

Behind the concept of vernacular theory lies a very simple idea: that it is worthwhile to listen to people with genuine respect and interest, to listen to what they say and how they say it, and to try to understand the situations from and to which they speak. Vernacular theory also asserts that theorizing is something people do constantly. Theory is not a rarified pastime; rather, it is crucial to our ability to understand and engage with ourselves, others, and the world. Vernacular theory too recognizes that, for many people much of the time, engaging with themselves, others, and the world is a fraught, difficult, and even dangerous undertaking; vernacular theories will often emerge from desperate situations, 
from painful encounters, from engagement with power structures weighted against the theorizer.

Vernacular theories sometimes emerge out of collective understandings. For instance, anthropologist Michael T. Taussig describes how an egalitarian community of Cameroonian subsistence farmers theorized new banana plantation owners as witches who transformed labourers into zombies (20). Yet, while vernacular theories may be developed in common, they can also be extremely idiosyncratic, individual bricolages. One way in which such vernacular theories can develop is through the experience of psychological breakdown, emerging perhaps in the form of voices, visions, or unusual thoughts and beliefs. A Question of Power articulates a deeply personal vernacular theory: a vernacular with one speaker. Drawing on sources including radical pan-Africanism, Egyptian mythology, and Hindu mysticism, Head constructs her theoretical practice in the manner of a bricoleur, in the sense defined by Claude Lévi-Strauss: her access to reading materials was limited, heterogeneous, and "the contingent result of all the occasions there have been to renew or enrich the stock" (qtd. in Deleuze and Guattari, Anti-Oedipus 8). Analyzing the damages wrought by power structures, Head utilizes fragments and shards, creating a sharp-edged theoretical mosaic. Brokenness is not only a fundamental characteristic of her theory but also a powerful analytical and creative tool in its own right.

The text's fragmentedness manifests in its disorienting, multilayered symbolism and its slippery structure. Sue J. Kim identifies some of the reasons why the text is so maddening: "A Question of Power is difficult because it does not adhere to any single axis of oppression or identification, but rather tries to take the full complexity of existence into account at once" (64n5). And Arthur Ravenscroft admits his inability "to have mapped out for my own ordered satisfaction the full values and equivalences of the myriad figures who people Elizabeth's [...] nightmares," or to properly trace "the extraordinarily comprehensive free-wheel ranging over cultures and their myths" (184). The text 
is densely webbed with connections and references, with expansive and contradictory symbolism. To take just one instance, the figure of Medusa in the novel not only refers to the Gorgon of Greek mythology but also functions as at least three different gods: her thunderbolts link her to Zeus; her killing Osiris positions her as Set; and she is likened to the Hindu goddess of illusions, Mahamaya (not to mention that she becomes Buddha's wife). Politically, she is connected to Nazism and Apartheid but also to African nationalism. Multiple referential frameworks are thus piled atop one another; they slip and shift and tumble. Within all these symbolic networks, there seems to be a deeply hidden, encoded coherence - if only one could track the imagery, uncover the pattern.

In attempting to trace this pattern, to discover the connections among Osiris and Hitler and Buddha, the reader is drawn into a state mimicking paranoia. As Jacqueline Rose writes, "I am not sure that it is possible to read this book without feeling oneself go a little bit mad" (404). Desiree Lewis argues that the novel's overabundance of signification is symptomatic of Head's own "paranoid perception": "In the same way that Head does in many of her letters, Elizabeth perceives 'some coherent, broad, overall pattern' and uncovers menacing forces concealed by everyday actions and behaviour" (199). The novel's theorizing, Lewis suggests, is paranoid, finding evil in innocence.

Lewis argues that Head's paranoia has generated a text which imposes a false coherence on the complexities of life. Yet, if we return to the novel, the phrase Lewis quotes above takes on quite a different meaning: "She struggled over and over to link the brief snapshots, the statements he made and the torture of certain states of mind, into some coherent, broad, overall pattern" (Head 40). The trouble is not, as Lewis posits, that Head imposes totalizing patterns in her work while ignoring the true multifaceted nature of experience: rather, Elizabeth suffers because she realizes the impossibility of finding coherence. She suffers because life and pain are too complex and intense to comprehend within a unified theory. Whenever Elizabeth articulates a theory of power, Head stresses its 
incompleteness, contingency, and origins in pain. Head's description of Elizabeth's intellectual efforts - "she struggled over and over again to link the brief snapshots" - resonates strongly with the reader's attempt to make sense of the novel and its flashes of disconnected imagery.

Susanna Zinato's The House Is Empty, in a dazzling feat of textual interpretation, offers a reading of the grammatical basis for the text's difficulties, locating and interpreting the "madness" of Head's text. She explains this approach to textual madness with a quotation from Shoshana Felman's La folie et la chose littéraire: "The more 'mad' a text is - the more, in other words, it resists interpretation - the more the specific modes of its resistance to reading themselves constitute its 'subject' and its literariness." ${ }^{1}$ Madness, in a text, constitutes resistance. The madness of the text is its program, in DeleuzoGuattarian terms, for the construction of a Body without Organs, a smooth space resisting "organ-ization" and striation.

In the case of A Question of Power, the text's elusiveness and sense of disconnection arise in part from peculiarities of syntax: clauses linked only with commas, semicolons, or the conjunction and - "the vaguest of linkers," Zinato notes, for it "does not make up for the absence of logical relations between clauses" (126). Head's grammar not only refuses to make proper connections but also deliberately creates disjunctions. As Zinato writes, "Full-stops [...] split up constructions that might have been easily conglobated in the same syntactic unit," while semicolons "fragment the sentence's inner structure" and maintain "the sense of an on-going flux; they separate and conjoin" (126). A Question of Power is thus constructed from a rickety grammar which refuses to specify relationships: "As a result of this fragmentation of the text into a series of minimal units, each clause is allowed to stand on its own feet and is accorded equal importance with the others" (Zinato 126). This is a radical style with radical

\footnotetext{
${ }^{1}$ My translation; the original reads: "Plus un texte est 'fou' - plus, en d'autres termes, il résiste à l'interprétation plus ce sont les modes spécifiques de sa résistance même à la lecture qui constituent son 'sujet,' et sa littérarité" (qtd. in Zinato 22).
} 
implications, and it may be likened to Deleuze and Guattari's concept of "nomad thought." As Brian Massumi writes in the foreword to A Thousand Plateaus:

Rather than analyzing the world into discrete components, reducing their manyness to the One of identity, and ordering them by rank, [nomad thought] sums up a set of disparate circumstances in a shattering blow. It synthesizes a multiplicity of elements without effacing their heterogeneity or hindering their potential for future rearranging (to the contrary). (xiii)

In her syntax, as in her plot, Head refuses to create solid, stable linkages. Atomized clauses, disconnected incidents, and kaleidoscopic imagery all confound Elizabeth's attempts to make sense of her world, while simultaneously creating a particularly open textual space across which meanings can proliferate. The loosened connections within the text, as well as the prose's astonishing variety, invite as well as frustrate the reader's own theoretical activities.

To theorize is painful, and all theories will be inadequate: not only does Head repeatedly dramatize this point, but too she has produced a text that forces readers and critics to experience the pain of theorization for themselves. This pain arises, in part, from our resistance to and unfamiliarity with the kind of radically open thought which Head practices and which she demands of us in return. The text is nomadic, mad, schizophrenic - and it demands a certain derangement from the reader, a disturbance and disruption of ordinary thinking patterns, of customary ways of relating to a text.

In A Question of Power, Head attempts to make a textual Body without Organs. Upon and within this Body without Organs, she enacts the damage done by power. At the same time, she uses the text to attempt the precarious project of opposing and evading power, while also cultivating creative potential for growth. For Head, theory must be close-range, because there is no safe remove from which to theorize and because access to such distance is itself a privilege of power. As Foucault writes, in his preface to Anti-Oedipus, power must be understood not as an external phenomenon but as "the fascism in us all, in our heads and in our 
everyday behavior, the fascism that causes us to love power, to desire the very thing that dominates and exploits us" (xiv-xv). To adequately theorize power without also reproducing it, Head suggests that one must have intimacy with suffering and with the compassion that arises from such suffering. As Sello the monk says in the novel (with his not entirely trustworthy wisdom), "Everything was evil until I broke down and cried. It is when you cry, in the blackest hour of despair, that you stumble on a source of goodness" (34). Intense personal suffering is a necessary precondition for any adequate theory of power or theory of goodness - and goodness, for Head, cannot exist except in opposition to power.

Throughout A Question of Power, Elizabeth engages in an intellectual struggle to make sense of her visions, to answer questions about good and evil, and to translate her suffering into understanding. Head frequently articulates Elizabeth's theoretical processes, as in this passage from the end of Part One:

Something was eluding her - the mystical madonna. How had all her wild fires quieted down into that still river of eternal abstraction of soul? [...] Elizabeth could only speculate. Perhaps at some dim time Medusa had encountered Perseus and, out of the death he had inflicted on her, risen again with a still, sad, fire-washed face. [...]

There was something more elusive still: Sello's African circumstances. He had half-indicated great resources of strength and goodness in his surroundings. Or what did the poor mean by: Take off your vesture garments? Did they, as the victims of those who had everything, also see into the nature of a soul like Sello's? [...] Humility, which is a platitude of saints and recommended for the good life, could be acquired far too drastically in Africa.

And still something eluded her. (99)

The key phrase in this passage is the refrain "And still something eluded her": Elizabeth grapples with fragmentary and oblique imagery - just as the reader must - while trying to push the resistant images beyond themselves into something that could help her (and the reader) to understand humility, 
transformation, and goodness. It is not a struggle which is ever fully or satisfactorily resolved, however: the images remain excessive and resistant to any full interpretation.

In the above passage, Head also brings us back to the divergence between communal and individual vernacular theories. Elizabeth hears the poor speaking, but she puzzles over their utterances - and these utterances come, of course, not from actual poor people but from Elizabeth's own mind. There are many different varieties of vernacular theory, and understandings across them are by no means assured. As Elizabeth struggles to understand power and decency, she repeatedly returns to images of "the poor" and "the victims of those who had everything" (99), figures who insist on humility, ordinariness, and the removal of crowns and vesture garments. In the book's first paragraph, Sello translates his "African" philosophy into "one of the most perfect statements: 'I am just anyone'" (11), and Elizabeth finds herself introduced to "one of the most complete statements for the future a people could ever make: Be ordinary" (39). Elizabeth venerates the poor and their philosophy of ordinariness, but they remain always separate from her and are at times hostile or confusing.

Elizabeth's individual theoretical efforts take place in relation to, but at a remove from, much larger collective projects of vernacular theory and critique: the poor appear as a kind of chorus, to which she must listen - without quite understanding what they say and without being able to join in (31-32). Nevertheless, she suspects that she and the poor are engaged in convergent projects: "Did they [...] also see into the nature of a soul like Sello's?" (99). In these hesitant, hopeful, and anxious searches for connection and translation between Elizabeth's thoughts and the theories of the poor, Head alludes to the existence of multiple and possibly complementary streams of vernacular theory, in Botswana and across Africa. There is a multiplicity of theories which question and challenge the political trends that Head explores in A Question of Power - and, indeed, it is within these popular vernacular theories that Head and Elizabeth 
most insistently locate wisdom and hope. As Elizabeth tells Tom, "Africa isn't rising. It's up already" (135).

Yet while Elizabeth and the novel itself attempt both sympathy and solidarity, they remain necessarily distanced from "the poor of Africa" (31), and this distance contains not only admiration but varying degrees of fear and mistrust. These elements of separation and ambivalence are translated into the accusations of Medusa and an "Asian man," a stock third-world revolutionary, who hisses, "You have never really made an identification with the poor and humble" (31); and Medusa, amplifying the message, shouts, "This is my land. These are my people. [...] I can do more for the poor than you could ever do" (38). There is a very upsetting tension here between Elizabeth's difference from the poor and her admiration of them, and this tension is exacerbated by the intensely conformist tendencies she perceives in the poor's anti-authoritarianism. It is an element of their vernacular theory with which Elizabeth and Head struggle to reconcile themselves.

Throughout the novel, Elizabeth is haunted by the phrase which she regards as a central tenet of the vernacular theory of the poor: "Be ordinary" (39). For Elizabeth, the ordinary becomes an ideal, but it is a troubling one: it represents the comforts of decency and simple humanity, but it also implies a narrow conformity within which she can never hope to find acceptance. As a child in the South African slums, Elizabeth learned that "[t]hey hated any black person among them who was 'important.' [...] She had seen too many people despised for selfimportance, and it was something drilled into her: be the same as others in heart; just be a person" (26). The trouble lies in what is necessarily elided here between ordinariness and conformity. Nevertheless, to Elizabeth, the ordinary seems to offer a response to the terrors of power:

People [in most advanced societies] had their institutions, which to a certain extent protected them from power-lusting presidents for life with the 'my people' cult. Africa had nothing, and yet, tentatively, she had been introduced to 
one of the most complete statements for the future a people could ever make: Be ordinary. Any assumption of greatness leads to a dog-eat-dog fight and incurs massive suffering. (38-39)

Here, Head implies, but does not make explicit, a connection between the ordinary and Africa's lack of institutional defenses. Africa's egalitarianism and lack of institutionalized hierarchies, Head suggests, makes it at once more vulnerable to dictatorship yet also primed to survive it - and even to replace it with radical democracy. The ordinary thus offers some shelter from the ravages of the powerful, a decency which can ameliorate suffering, and a social matrix which allows life to continue in spite of abuses of power. The ordinary is the answer to importance, in that it offers some defence against the onslaught of power, but also - and this is the danger - in that one implies the other. The same lack of institutions seems to generate both dictatorship and veneration of the ordinary. Further, insofar as it demands conformity, the ordinary can be co-opted as a tool of "power people" (38) to facilitate dictatorial abuses. Its egalitarianism has the potential to become repressively narrow.

This double-edged ideal of the ordinary allows us to understand the sense in which "Medusa was expressing the surface reality of African society. It was shut in and exclusive. It had a strong theme of power-worship running through it, and power people needed small, narrow, shut-in worlds" (38). The "shut-in" conformism latent within the vernacular theory of power is open to abuse by the powerful: "When someone says 'my people' with a specific stress on the blackness of those people, they are after kingdoms and permanently child-like slaves" (63). Blackness, here, in reference to African nationalist rhetoric, refers to race which has been reified into a fixed identity.

How does an isolated person like Elizabeth, living on the edges of society, in a strange position of simultaneous privilege and vulnerability, sincerely connect to poor locals from whom she is so distanced? How can a highly eccentric text like $A$ Question of Power genuinely revere the ordinary? How can such an individual 
vernacular theory of power connect to broader struggles and avoid becoming reified into an artefact of elite culture? These anxieties surface in the text during Elizabeth's dinner party encounter with Danish literature. Camilla boasts, "It takes a certain level of education to understand our novelists. The ordinary man cannot understand them..." (79), making a statement which seems, ironically, to describe A Question of Power. Elizabeth reflects that "those authors had ceased to be of any value whatsoever to their society - or was it really true that an extreme height of culture and the incomprehensible went hand in hand?" (79).

How can Head justify the incomprehensibility of her text? The difficulty of $A$ Question of Power is not an intentionally elitist gesture but, rather, as we have seen, the mark of an embattled theory. Actively engaged in the struggles that it theorizes, A Question of Power encounters difficulties and contradictions that can be acknowledged but not eliminated. Even if we understand the origins of the text's difficulty, the result is a novel which is far less approachable than, for example, When Rain Clouds Gather - and this has, of course, affected its reception.

A Question of Power has been particularly poorly received in Botswana, as Mary S. Lederer and Leloba S. Molema, of the University of Botswana, detail. They write that Head remains "largely unknown in the country she adopted and made famous in her work"; those who did know her regarded her as "just an outsider or 'that madwoman in the village"' (110). (This opinion may be changing, however, due to the successful adoption of an abridged version of When Rain Clouds Gather as a secondary school set text in 1998 [119].) When Lederer and Molema have taught A Question of Power to second-year students at the University of Botswana, the novel has been poorly received by confused students (112), which may be a result of the novel's difficulty, placing it in the same category of elitist culture as the incomprehensible Danish novels praised by Camilla.

However, another lecturer, Tholagango Mogobe, suggested to Lederer and Molema that student antipathy was caused not only by the difficulty of the text but also by Head's approach to race and gender: "He feels the problems Head 
raises are not perceived as problems, because there is a vested interest in preserving the cultural status quo" (114). The radicalism of A Question of Power, in content as well as in form, sets the novel necessarily beyond and against the status quo, not only of governmental power but also of the more intimate power dynamics lived (and perhaps even cherished) by ordinary people.

One of the text's final moves, however, is an attempt to eliminate this troubling and persistent contradiction between the ordinary and the eccentric. Elizabeth tries to mend this crack with an act of translation: "when a people wanted everyone to be ordinary it was just another way of saying man loved man" (206). This translation temporarily satisfies her, and it allows the text to conclude with that cathartic, reassuring "gesture of belonging" (206). Yet even as Elizabeth seems to resolve this contradiction for herself, Head reflexively reasserts it with regards to the novel itself. Elizabeth turns to Premchand's 1936 novel, The Gift of a Cow, which "exalted the poor" in contrast to "a literature of magic, of ghosts, of high-born heroes and heroines" (Head 206). This reference provides an ironic conclusion to the work in which Head turns away from the social realism of her first two novels, When Rain Clouds Gather and Maru, producing a novel in the fantastic mode, replete with magic, ghosts, and gods. The "gesture of belonging" is a moment of hope - but, rather than provide a final stability, it is merely a temporary and partial respite for a project and a character seeking to form connections from positions of difficulty and strangeness.

There is, however, another level on which to read Head's injunction to "be ordinary" and her "gesture of belonging": not as straightforwardly social or political, but as a spiritual question concerning the fundamental nature of reality. For the eccentric and outcast, becoming ordinary involves a destruction of identity, and this self-annihilation, according to Deleuze and Guattari, as well as to Hinduism and Buddhism, is a necessary step in the realization that all identity and separation is illusory. As Peter Hallward writes, this form of awakening 
requires "the active dissolution of the self as such" so that "the merely 'one' becomes-imperceptible in the One" (10).

As she grapples with the impossibility of belonging, Elizabeth undergoes a series of mental transformations which erode her selfhood. At the end of all becomings, Deleuze and Guattari argue, is "becoming imperceptible." What does it mean to become imperceptible? "A first response would be: to be like everybody else" (A Thousand Plateaus 308). To engage constantly in becomings is to shed the particularities and tensions which preserve individuality and identity, opening the way for a merging with the world. In trying to "be ordinary," Elizabeth struggles with imposed identities as well as with a morality at once Manichean and ambiguous. She is tortured by unsustainable dualisms, to which her involuntary, unconscious response is a series of splittings, transformations, and becomings. As Deleuze and Guattari write, "The only way to get outside the dualisms is to bebetween, to pass between, [...] never ceasing to become" (A Thousand Plateaus 305).

If we understand the figures who torment Elizabeth as products of her mind, as dreams or hallucinations, then we recognize that she becomes all of them. She becomes Sello, Medusa, and Dan, as well as all the rest of the phantasmagorical cast, while also remaining herself in the world. She passes between man and woman, between good and evil, between omnipotence and abjection. More importantly, she not only crosses between these dualities but also occupies both poles simultaneously: she is at once persecutor and her own suffering self. Such relentless, uncontrollable becomings are terribly painful. As Head writes, "What sort of gymnast was she supposed to be, so overstrained between concepts of good and evil?" (109). The process is torturous, a destructive creativity by which the one is shattered into the many.

This process of disintegration, in which a person's singular identity is shattered into the many intensities of human history, produces what Deleuze and Guattari call the Body without Organs, a state in which the personalities of history and mythology become translated into sensations (Anti-Oedipus 23). The Body 
without Organs is a condition in which social signifiers slip away and formal structures of organization collapse, leaving nothing but abstract forces: "The BwO [Body without Organs] is what remains when you take everything away" ( $A$ Thousand Plateaus 168). In a late essay, Deleuze also referred to this undifferentiated condition as "pure immanence," in which "[t]he life of the individual gives way to an impersonal yet singular life" (Pure Immanence 28).

As a condition without individuation or definition, a Body without Organs is characterized not by identities but by the intensities that flow across it. The question is: what kinds of intensities pass, and what kinds of Bodies without Organs do different intensities create? The Body without Organs is what happens when one removes oneself from the structures and strictures of social organization: it is what exists before, beneath, or against socializing processes and subject formation; the absence, loss, or collapse of ego (A Thousand Plateaus 176). There are, clearly, many ways to come loose from society and many ways to lose selfhood, ranging from Buddhist enlightenment to schizophrenic dissolution. Elizabeth has disconnections and dislocations imposed upon her by systems of power, and the combined efforts of Apartheid South Africa, missionary Christianity, and Botswana authorities deterritorialize her catastrophically. Elizabeth suffers through much of the novel from the ravages of intensities channeled or blocked by Sello, Medusa, and Dan, figures who function as manifestations and embodiments of power. Her separation from society and her collapse of selfhood are the result of accumulated abuses imposed on her by intersecting power structures; none of her deterritorializations is voluntary. Her Body without Organs is created by power's abuses, and, as a result, it is characterized by pain and abjection, in danger of total collapse and annihilation.

Elizabeth has been forcibly deterritorialized to such an extent that power has destroyed her ability to maintain a viable sense of self. The interconnected narratives of self, memory, and social position break down; even the deep, fundamental narratives of linear time and corporeal integrity fail. As Zinato 
argues, this crisis of identity is translated into a straining and cracking of language itself (127). Rose, similarly, writes that A Question of Power "expose[s] [...] the delusional component behind any uncritical belief that text or speaker simply speak" (403). The novel destabilizes language, and, through this subversion, it destabilizes narratives of self. Zinato writes that the goal of A Question of Power seems to be "disrupting in the reader any illusion that he/she is listening to a unique, self-possessed, speaking subject" (129). Head challenges the stories of self and illusions of coherence: in this way, the text's difficulty and disruptiveness can be read as emancipatory tactics in a campaign against the constraints of identity.

Elizabeth's spectral tormentors embody the processes by which she is transformed into an abject Body without Organs. The processes are illustrated in some of the novel's more opaque passages, those which, in Zinato's words, "enact [...] a "physics of power'" (135). This physics is the means by which destructive intensities can be circulated across a disempowered and eventually de-subjectified body, producing an abject Body without Organs. The development of this physics of power can be seen in those passages where imagery gives way to pure sensation: lights, electricity, waves, and roaring, all directed by the "power people." And Sello, accordingly, transforms Elizabeth's body into

channels through which raced powerful currents of energy. He kept on switching off and adjusting the currents[,] [...] until one day her head simply exploded into a sea of pale, blue light. It was the sensation which accompanied it which was so final and absolute: Here is the end of all life. Here is nothing. (36)

Dan performs a similar operation, although even more explicitly technological: "[H]e had to fix up his electrical wiring system (her whole body was a network, a complicated communication centre)[.] [...] This was his version of God" (126). Dan also invades her more grossly. Head describes him as 
a supreme pervert thrust[ing] his soul into your living body. [...] It was like no longer having a digestive system, a marvelous body, filled with a network of blood-vessels - it was simply having a mouth and an alimentary tract; food was shit and piss; the sky, the stars, the earth, people, animals were also shit and piss. (138)

Sello and Dan, with their respective programs of ascetic morality and pornographic degradation, convert Elizabeth into different kinds of emptied Bodies without Organs: the mystical and the abject. Neither of these Bodies without Organs, holy or obscene, "correspond[s] to the energies needed for the tasks of life; making tea, cooking food for a small boy, eating, washing, working" (Head 36). Instead, each version is an isolating experience, separating her from any possible connections: as an electrical circuit, she is complex but closed, connected only to the guru's switchboard; as a vehicle for "shit and piss," she is reduced to the basest terms of her corporeality.

Elizabeth's deterritorializations have been too drastic, uncontrolled, and traumatic, which cause her to become an empty Body without Organs, on the brink of suicide. Deleuze and Guattari comment on this danger inherent in the project of trying to remove oneself from structures of identity and power: "Staying stratified - organized, signified, subjected - is not the worst that can happen; the worst that can happen is if you throw the strata into demented or suicidal collapse, which brings them back down on us heavier than ever" ( $A$ Thousand Plateaus 178). We might understand the jumbled nightmares of Elizabeth's visions as just such a "demented or suicidal collapse" of her personal stratifications: race, sex, power, and identity crash down on her, manifesting in a tangled wreckage of signifiers and sensations.

Traumatized, dislocated, and isolated, Elizabeth becomes dislodged from all forms of social belonging, to the extent that she even seems wistful about the intimate cruelties of witchcraft (from which she is excluded): "People don't care here whether foreigners get along with them or not. [...] They have a saying that 
Batswana witchcraft only works on a Motswana, not an outsider" (A Question of Power 56). What she needs is to form connections, since " $[\mathrm{t}]$ oo much isolation isn't a good thing for anyone," as Eugene tells her when he invites her into his cooperative industries project (56). The project - particularly the garden Elizabeth establishes within it - functions as a model for the kinds of connections and disconnections people need in order to thrive. Head's imagery, as she writes about the personal and communal therapeutic potentials of the garden, is interestingly close to that of Deleuze and Guattari's when they recommend a strategy for creating a full Body without Organs - that is, a life beyond ego and power structures, which thrives and blossoms rather than withering away:

Lodge yourself on a stratum, experiment with the opportunities it offers, find an advantageous place on it, find potential movements of deterritorialization, possible lines of flight, experience them, produce flow conjunctions here and there, try out continuums of intensities segment by segment, have a small plot of new land at all times. It is through a meticulous relation with the strata that one succeeds in freeing lines of flight, causing conjugated flows to pass and escape and bringing forth continuous intensities for a BwO. Connect, conjugate, continue[.] (A Thousand Plateaus 178)

The key is to cause intensities to flow and pass, and to flow correctly: not too much, not too little. Crucially, such flows cannot be achieved in isolation: by advising the reader to "[c]onnect, conjugate, continue," Deleuze and Guattari emphasize the importance of cooperative communities in the creation of new modes of living. The isolated Body without Organs is at risk of emptiness and collapse. There can be no sustainable "individual" transformation without at least small pockets of communal transformation, and such transformations should be imagined not simply in terms of lines of flight - motion, rootlessness, escape but also in terms of growth and cultivation. The importance of the experimental community gardens in A Question of Power is no accident. 
When Elizabeth's consciousness divides into the many figures that guide and torment her - stretched across that painful arc between good and evil, becoming God and the devil at the same time - she not only becomes a Body without Organs: she becomes everybody. This is not, as Deleuze and Guattari point out, the "everybody" which is an aggregate of isolated individuals; instead, it is a "becoming everybody/everything [...] that brings into play the cosmos with its molecular components" (A Thousand Plateaus 308). The everybody of masses, of self-contained individual units, is opposed to an everybody conceived of as something much finer and less stable, given to interminglings and recombinations. The molar unit disintegrates into its component molecules, and the individual, after many becomings, dissolves into union with the world. Such a becoming everybody/everything is the result, then, not only of a series of becomings but also of loss, elimination, dismemberment, or pulverization.

Elizabeth suffers through just such processes in her becomings: "She was losing track of the personality pattern she'd lived with since birth" (Head 131). Her suffering is the interconnected sufferings of the world, so that "if she cried about one thing, she cried about other things too. Pain was not only pain. It was a blinding daze of agony piling up on all sides" (68). Yet it is through these extremes of empathy - in which she not only feels for but becomes, all at once, sufferer and oppressor - that Elizabeth is finally able to become ordinary and belong to the world in this intermingled sense.

In becoming imperceptible, the individual vanishes. Deleuze and Guattari describe a camouflaged fish able to blend in with its environment as an example of becoming imperceptible, but they describe it in startlingly violent terms: "this fish is crisscrossed by abstract lines that resemble nothing, that do not even follow its organic divisions; but thus disorganised, disarticulated, it worlds with the lines of a rock, sand, and plants, becoming imperceptible" (A Thousand Plateaus 308-9). Elizabeth, in becoming imperceptible, must be "disorganised, disarticulated" so that she may "world" with Botswana. Head describes the euphoric result: 
To rediscover that love [with Sello] was like suddenly being transported to a super-state of life. It was the point at which all personal love had died in them. It was the point at which there were no private hungers to be kissed, loved, adored. And yet there was a feeling of being kissed by everything; by the air, the soft flow of life, people's smiles and friendships[.] [...] That was the essential nature of their love for each other. It had included all mankind, and so many things could be said about it, but the most important was that it equalized all things and all men. [...]

And from the degradation and destruction of her life had arisen a still, lofty serenity of soul nothing could shake. (202)

Her love for Sello is impersonal and non-sexual, in part because it is love not of another but of herself, a compassionate acceptance of her own corruptibility, her own struggle between spiritual questing and earthly attachment. It is a selfacceptance which radiates outwards into "the soft flow of life," indicating an understanding of a fluid world which easily, naturally moves through barriers. Her personal desires dissolve, allowing the "equaliz[ing] of all things and all men" as she becomes imperceptible, becomes everybody and everything.

The directive to be ordinary, then, is entirely in keeping with the novel's vernacular transformations of Buddhist and Hindu spirituality: it points towards a spiritual death of the ego, allowing for unity with the ultimate creative potentiality contained within the void. As Hallward writes, "only self-extinction provides access to the quintessentially singular realm of sunyata, i.e. pure Creative emptiness as such, a creativity unlimited by creaturely actuality" (11). Despite its apparent simplicity, the mantra "Be ordinary" enters into the game of dualism and ambiguity that runs throughout the text. It urges surrender and transformation, conformity and transcendence, the imposition of identity and the dissolution of all identities. It is an oppressive tool, and it points towards enlightenment.

What is learned is that the free and self-authenticating person is permanently on the run from the strictures of identity and the intimate operations 
of power. Elizabeth gains the freedom to slip through the clutches of power but not to escape the stinging friction of contact. Her moments of peace are purchased with the knowledge of a world of suffering. Although A Question of Power achieves a quiet resolution, it does not convince the reader that all is finally well with Elizabeth. And this is precisely because all is not finally well. Elizabeth, the shattered individual whom Head depicts, does not achieve a quiet, coherent, stable sense of self. What she achieves is the realization that being a whole person requires one to participate endlessly in the troubled lives of the world. Wholeness is a process of becoming rather than a final security, and a central, continuing element in this becoming is the experience of pain and destruction. When Elizabeth falls asleep at the end of the novel, the reader knows only too well what dreams may come.

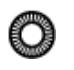

\section{Works Cited}

Bignall, Simone, and Paul Patton. "Deleuze and the Postcolonial: Conversations, Negotiations, Mediations." Deleuze and the Postcolonial, edited by Simone Bignall and Paul Patton, Edinburgh UP, 2010, pp. 1-19.

Burns, Lorna, and Birgit M. Kaiser, editors. Postcolonial Literatures and Deleuze. Palgrave Macmillan, 2012.

Deleuze, Gilles. Pure Immanence: Essays on a Life. Translated by Anne Boyman, Zone, 2001.

Deleuze, Gilles, and Félix Guattari. Anti-Oedipus. 1972. Translated by Robert Hurley, Mark Seem, and Helen R. Lane, Continuum, 2004.

-. A Thousand Plateaus. 1980. Translated by Brian Massumi, Continuum, 2004. Foucault, Michel. "Preface." Deleuze and Guattari, Anti-Oedipus, pp. xiii-xvi. Hallward, Peter. Absolutely Postcolonial: Writing Between the Singular and the Specific. Manchester UP, 2001.

Head, Bessie. A Question of Power. Heinemann, 1974. 
Kim, Sue J. "“The Real White Man Is Waiting for Me': Ideology and Morality in Bessie Head's A Question of Power." College Literature, vol. 35, no. 2, 2008, pp. 38-69.

Lederer, Mary S., and Leloba S. Molema. “'That Troublemaker': Bessie Head in Botswana." Emerging Perspectives on Bessie Head, edited by Huma Ibrahim, Africa World, 2004, pp. 109-20.

Lewis, Desiree. Living on a Horizon: The Writings of Bessie Head. Africa World, 2007.

Massumi, Brian. "Translator's Foreword: Pleasures of Philosophy." Deleuze and Guattari, A Thousand Plateaus, pp. ix-xvi.

McLaughlin, Thomas. Street Smarts and Critical Theory: Listening to the Vernacular. U of Wisconsin P, 1996.

Ravenscroft, Arthur. "The Novels of Bessie Head." Aspects of South African Literature, edited by Christopher Heywood, Heinemann, 1976, pp. 174-86.

Rose, Jacqueline. "On the 'Universality' of Madness in Bessie Head's A Question of Power." Critical Inquiry, vol. 20, no. 3, 1994, pp. 401-18.

Spivak, Gayatri Chakravorty. "Can the Subaltern Speak?" Colonial Discourse and Post-Colonial Theory, edited by Patrick Williams and Laura Chrisman, Columbia UP, 1993, pp. 66-111.

Taussig, Michael T. The Devil and Commodity Fetishism in South America. U of North Carolina P, 1980.

Zinato, Susanna. The House Is Empty: Grammars of Madness in J. Frame's Scented Gardens for the Blind and B. Head's A Question of Power. CLUEB, 1999.

Elinor Rooks is an independent researcher in African literature, history, and culture. She completed her PhD at the University of Leeds; her dissertation, "Vernacular Critique, DeleuzoGuattarian Theory and Cultural Historicism in West African and Southern African Literatures," focused on the novels of Bessie Head and Amos Tutuola. She is currently researching responses to the Ebola epidemic in West Africa and is authoring a book on Tutuola. 